\title{
Analisis Gaya Kepemimpinan Kepala Sekolah Dalam Penerapan Manajemen (Study Kasus Sekolah Dasar Al-Azhar Sriwijaya Palembang)
}

\author{
${ }^{1}$ Mohammad Zalmi Kahardani, ${ }^{2}$ Mohammad Trisamanta, ${ }^{3}$ Medya Apriliansyah, \\ ${ }^{4}$ Wylen Djap, ${ }^{5}$ Trifiana Tiodora \\ Program Studi Doctoral DRM Education \& Leadership of Universitas Pelita \\ Harapan, Jakarta, Indonesia

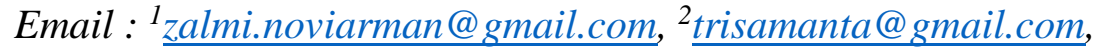 \\ 3.medya.apriliansyah@gmail.com, ${ }^{4}$ wylen230499@gmail.com, \\ 5anatobing@gmail.com
}

(Diterima: Oktober 2021; Direvisi: Oktober 2021; Dipublikasikan: Januari 2022)

\begin{abstract}
ABSTRAK
Tujuan penelitian ini untuk mengetahui analisis gaya kepemimpinan kepala sekolah khususnya di Sekolah Dasar Islam Al-Azhar Sriwijaya Palembang. Pendekatan penelitian adalah kualitatif dengan menggunakan metode study kasus dan objek penelitianya adalah Sekolah Dasar Al-Azhar Sriwijaya Palembang serta subjek penelitiannya adalah kepala sekolah dan karyawan. Teknik pengumpulan data pada penelitian ini dilakukan melalui wawancara dan oberservasi. Dari hasil penelitian, ini dapat diketahui bahwa 1) Bagaimana gaya kepemimpinan kepala sekolah khususnya di Sekolah Dasar Islam Al-Azhar Sriwijaya dan 2) Gaya kepemimpinan kombinasi terbukti lebih baik dibandingkan dengan gaya kepemimpinan tunggal untuk digunakan di sekolah.
\end{abstract}

\section{Kata Kunci: Gaya Kepemimpinan, Kepala Sekolah, Manajemen Sekolah, Sekolah Dasar}




\section{PENDAHULUAN}

Kepala sekolah memiliki peran penting dalam menanggapi meningkatnya tuntutan masyarakat modern akan manajemen sekolah yang efektif. Mereka mungkin mengadopsi gaya kepemimpinan yang berbeda, dan ini bisa menjadi parameter penting untuk keberhasilan sekolah dan kepemimpinannya. Dalam konteks ini, kepala sekolah merupakan parameter kunci dalam memastikan pertumbuhan, pencapaian tujuan, dan kesuksesan perusahaan. Pimpinan sekolah diharapkan melakukan tugas yang kompleks dan bertindak baik sebagai manajer maupun pemimpin. Peran mereka meliputi: dukungan kepada guru, siswa dan orang tua; berhubungan dengan orang tua dan pemangku kepentingan lainnya. Rentang tugas, kompleksitas dan peran multidimensi ini dapat digambarkan sebagai seni memimpin. Seni kepemimpinan sangat penting bagi sekolah untuk menjadi efektif di bawah variabel sekolah internal dan eksternal tertentu, termasuk harapan orang tua dan masyarakat, beban kerja guru dan iklim sekolah termasuk budaya perubahan dan inovasi. Kepala Sekolah dapat menunjukkan berbagai gaya kepemimpinan sesuai dengan kebijakan sistem pendidikan nasional, ciri kepribadian, nilai, pengalaman dan keterampilan mereka, serta masalah tertentu dan parameter lingkungan dari unit sekolah mereka. Faktanya, pemimpin yang efektif dapat menyesuaikan gaya kepemimpinan mereka tergantung pada konteks dan situasi unit sekolah mereka (Sunaengsih, et al., 2019).
Perlunya

peningkatan kepemimpinan sekolah telah menjadi prioritas utama untuk reformasi sekolah di Indonesia. Hal ini menjadi perlu, mengingat tantangan dan keluhan yang dihadapi pengelolaan sekolah-sekolah tersebut dalam satu dekade terakhir. Namun, karena kepentingan strategis sekolah, reformasi dipandang penting untuk pembangunan sekolah demi kepentingan bangsa. Sebagian besar variabel sekolah, yang dianggap terpisah, memiliki pengaruh paling signifikan terhadap pembelajaran. Kepemimpinan adalah yang kedua setelah pengajaran di kelas di antara faktor-faktor terkait sekolah yang mempengaruhi pembelajaran siswa di sekolah. Kepemimpinan adalah kegiatan transaksional dan transformasional yang sering terjadi antara pengikut dan pemimpin. Peneliti berpendapat bahwa, kepemimpinan mencakup kepatuhan pada tujuan bersama, kemampuan efektif terhadap bawahannya untuk mencapai tujuan yang telah ditetapkan. Beberapa sarjana telah mendefinisikan kepemimpinan dalam banyak hal seperti proses pengaruh sosial (Abdulrasheed, Hussin \& Kasa, 2016).

Dari definisi di atas jelaslah bahwa kepemimpinan terjadi dalam kelompok, kepemimpinan melibatkan pengaruh perilaku dan termasuk perhatian kolektif terhadap tujuan organisasi. Pemimpin sekolah dituntut untuk memiliki kualitas profesional seperti jujur, pemberdayaan masyarakat, inspirasi, memberikan contoh yang baik, memimpin perubahan, pemimpin visioner, berwawasan ke depan dan menunjukkan kompetensi dalam 
posisi kepemimpinan. Kepala sekolah sebagai pemimpin merupakan liaison officer yang menjadi perantara antara sekolah dan masyarakat. Perannya sebagai kepala sekolah adalah menggerakkan staf pengajar dan nonguru untuk mencapai tujuan sekolah. Kepemimpinan sebagai posisi dominasi dan prestise disertai dengan kemampuan untuk mengarahkan, memotivasi dan membantu orang lain dalam mencapai tujuan tertentu. Kepala sekolah memiliki tugas untuk memimpin, membimbing, melaksanakan, mengarahkan dan memotivasi baik staf pengajar maupun non-pengajar menuju pencapaian tujuan dan sasaran sekolah. Posisi utama adalah pekerjaan bertekanan tinggi dalam konteks supervisi instruksional. Ini juga merupakan pekerjaan yang remunerasinya kurang dibandingkan dengan tanggungjawab yang menyertainya (Abdulrasheed \& Bello, 2015).

Konsep manajemen berbasis sekolah merupakan hasil krisis yang berasal dari fleksibilitas dan struktur kendali yang ada dalam sistem sekolah. Jadi, saran untuk meningkatkan akuntabilitas, kontrol terhadap bawahan, konstruksi tujuan yang komprehensif dan spesifik, dan kontrol yang ketat terhadap oposisi besar menganut konsep looselycoupled yang artinya memiliki kendali yang longgar atas individu atau unit memungkinkan untuk bergerak bebas tanpa perlu koordinasi dan kendali, akuntabilitas dan kolaborasi muncul sebagai alternatif. Selain itu pengaruh, peran dan akuntabilitas kepala sekolah dan guru akan meningkat dalam pengelolaan dan penyelenggaraan sekolah yang lebih baik dari pada cara tradisional. Ini berarti beban kerja tambahan, dan bahkan manajemen risiko dan akuntabilitas administrasi kepala sekolah (Vally \& Daud, 2015).

Manajemen sekolah yang efektif merupakan faktor yang dapat mempengaruhi kualitas Pendidikan. Dilihat dari perspektif manajemen, sekolah yang efektif mengupayakan pemanfaatan yang optimal dari seluruh komponen sekolah. Sebagai lembaga pendidikan formal, sekolah dituntut untuk menghasilkan lulusan yang memiliki kemampuan akademik, keterampilan, sikap dan mental, serta kepribadian yang kompeten sehingga peserta didik memiliki daya saing setelah lulus dari suatu lembaga. Sekolah yang memiliki kepemimpinan kepala sekolah yang kuat diharapkan mampu mengembangkan manajemen sekolah yang efektif, karena didukung oleh berbagai aspek, seperti penerapan teknologi, budaya sekolah, sistem informasi, dan organisasi yang berkembang (Vally \& Daud, 2015).

Al-Azhar Sriwijaya Palembang adalah salah satu sekolah dasar yang sedang concern dalam meningkatkan kemampuan kepemimpinan kepala sekolahnya. Telah berdiri sejak 2013, dan telah memiliki 60-an karyawan, 352 siswa, dan 500 lebih alumni. Manajemen sekolah Al-azhar Sriwijaya sangat memperhatikan pelayanan, dimana peran dan gaya kepemimpinan kepala sekolah merupakan salah satu hal vital yang menentukan kesuksesan tersebut kedepannya, tentunya dapat membuat suatu manajemen yang baik kedepannya. Berdasarkan latar belakang penelitian diatas, rumusan masalah penelitian ini adalah 
bagaiamana efektifitas gaya kepemimpinan kepala sekolah khususnya di Sekolah Dasar Islam Al-Azhar Sriwijaya. Dimana tujuan penelitian ini ingin mengetahui efektifitas gaya kepemimpinan kepala sekolah khususnya di Sekolah Dasar Islam Al-Azhar Sriwijaya.

Adapun metode penelitian yang digunakan adalah studi kasus dengan pendakatan kualitatif. Objek penelitianya adalah Sekolah Dasar Al-Azhar Sriwijaya Palembang serta subjek penelitiannya adalah kepala sekolah dan karyawan. Teknik pengumpulan data pada penelitian ini dilakukan melalui wawancara dan oberservasi.

\section{TINJAUAN PUSTAKA}

\section{Manajemen Sekolah}

Manajemen sekolah

mengacu pada sarana struktural yang mengkoordinasikan upaya staf untuk mencapai tujuan yang ditetapkan, dan tujuan sekolah dengan menggunakan sumber daya yang tersedia secara efektif. Manajemen sekolah sebagai proses membimbing dan mengarahkan guru dan staf administrasi menuju pencapaian tujuan sekolah. Kepala sekolah harus menyediakan fasilitas yang memadai bagi guru dan staf administrasi untuk mencapai tingkat pencapaian tertinggi dan untuk meningkatkan pertumbuhan profesional secara maksimal. Atas dasar pengelolaan sekolah yang efektif dan efisien, kepala sekolah perlu memastikan bahwa, jenis orang yang tepat dengan keterampilan yang dibutuhkan dipekerjakan pada waktu yang tepat untuk melaksanakan berbagai pekerjaan dan layanan demi kemajuan sekolah. Manajemen sekolah menyiratkan proses perencanaan, pengorganisasian, pelaksanaan, pengarahan, dan evaluasi kebijakan pendidikan melalui pendanaan yang tepat untuk pembangunan pendidikan. Pengelolaan sekolah melalui mekanisme yang efektif dan efisien sangat penting untuk pembangunan berkelanjutan di sektor pendidikan. Faktor-faktor ini termasuk prosedur penerimaan, penetapan arah, perencanaan, strategi pengajaran dan pemanfaatan sumber daya, pengendalian dan peningkatan standar sekolah. Sekolah didirikan di tengah masyarakat untuk memenuhi kebutuhan pendidikan anak-anak. Orang tua berkeinginan untuk diberitahu tentang kemajuan anaknya disekolah secara bertahap. Sehingga berdasarkan kondisi tersebut, dipastikan bahwa hubungan kepala sekolah-orang tua yang baik mengarah pada efektivitas sekolah yang lebih baik. Sedangkan dukungan orang tua yang memadai terhadap guru akan memfasilitasi hasil belajar siswa yang positif di sekolah (Abdulrasheed, Hussin \& Kasa, 2016).

\section{Kepemimpinan (Leadership)}

Gaya kepemimpinan adalah proses yang mempengaruhi jalannya proses manajerial dalam suatu organisaasi. Gaya kepemimpinan merupakan "suatu bentuk dari sikap, pola atau tingkah laku yang ditampilkan pemimpin (dalam hal ini adalah 
kepala sekolah) yang dilakukan secara konsisten untuk mencapai tujuan" (Sutanto \& Setiawan, 2000:144; Husnan dan Heidjrachman, 2002:224; Wahyudi, 2009:123). Kepala Sekolah dalam menjalankan peran kepemimpinannya secara berhasil, kepala sekolah mutlak harus memiliki gaya kepemimpinan yang tepat (Ditjen Peningkatan Mutu Pendidik dan Tenaga Kependidikan, 2007:11) Eksperimen menunjukkan bahwa gaya kepemimpinan memang dapat mempengaruhi iklim organisasi, motivasi pekerja dan kinerja organisasi (Litwin dan Stringer 1968). Blazer membangkitkan motif pencapaian melalui kombinasi informalitas, keterlibatan, dan penekanan pada keunggulan kinerja, dan dengan mudah menjadi perusahaan yang paling sukses. Sebaliknya, Lingkungan Booker yang diatur secara ketat mendorong karyawan untuk mogok, menyebabkan percobaan berakhir setelah delapan hari daripada sepuluh yang dimaksudkan. Di Era sekarang, tidak cukup bagi seorang kepala sekolah untuk hanya mengandalkan pertemuan offline dengan stakeholders sekolah. Kepala sekolah juga diharapkan dapat "hadir" di sosial media. Fasilitas ini harus di maksimalkan dan diharapkan penggunaannya dapat memberikan value lebih untuk sekolah dari waktu ke waktu.

\section{Konsep Kepemimpinan Kepala Sekolah}

Secara khusus, kepala sekolah memainkan peran yang sangat penting dalam mempromosikan kinerja guru di sekolah. Kepala sekolah secara langsung atau tidak langsung mempengaruhi kinerja guru melalui gaya kepemimpinannya. Mempertahankan standar kurikuler, menilai metode pengajaran, mengawasi pencapaian siswa, memfasilitasi guru, dan membuat pengaturan untuk menciptakan lingkungan yang mendorong dan berorientasi pada pencapaian untuk mencapai tujuan yang menantang adalah beberapa peran dan fungsi kunci dari kepala sekolah. Menghilangkan hambatan dan memperjelas jalur bagi guru untuk melaksanakan tugasnya adalah aspek penting dari efektivitas teori jalur tujuan dan kepemimpinan yang efektif. Secara keseluruhan, kepala sekolah memberikan dukungan baik dalam bidang akademik maupun administrasi melalui serangkaian arahan dan instruksi untuk melaksanakan tugas dan mencapai tujuan yang menantang, sebagai fasilitator dan pemecah masalah. Kepemimpinan yang efektif melibatkan penyediaan serangkaian arahan yang mencakup rencana tindakan; Misalnya, bagaimana dan kapan menerapkan, memotivasi pengikut, menetapkan tujuan yang menantang, menjaga hubungan persahabatan, dan sebagainya. Banyak penelitian empiris telah dipublikasikan tentang efektivitas teori jalur tujuan untuk memvalidasi efek langsung dari empat gaya kepala sekolah terhadap kinerja guru. Namun, pengajuan ini hanya memberikan 
sebagian konsensus, karena mereka mendokumentasikan kinerja guru secara holistik. Pentingnya bidang kepemimpinan pada dasarnya didukung oleh teori sumber daya pribadi dan material. Dalam konteks pendidikan, kepala sekolah yang efektif mendorong guru untuk mengambil risiko dan mencoba metode pengajaran baru di kelas mereka, memastikan guru memiliki sumber daya yang mereka butuhkan. Selain itu, mereka membawa guru ke dalam kontak dengan ide-ide baru. Selanjutnya, kepala sekolah yang berfokus pada perubahan sekolah digambarkan sebagai strategi dalam upaya mereka untuk memperoleh sumber daya, baik uang dan gagasan dari lingkungan eksternal. Singkatnya, kepala sekolah yang efektif memandang penyediaan sumber daya lebih dari uang atau persediaan sebagai dorongan sumber daya manusia yang membantu fakultas dan siswa mencapai kesuksesan (Imhangbe, Okecha \& Obozuwa, 2018).

\section{Gaya Kepemimpinan dan}

Peningkatan Sekolah

Kepala Sekolah adalah pemimpin tertinggi di sekolah., Kepala sekolah harus memiliki strategi tersendiri dalam mengambil hati orangtua dan siswa untuk dapat menentukan pilihan di sekolah tersebut. Mendapatkan siswa baru setiap tahunnya merupakan kunci dari sustainability sekolah agar tetap bertahan. Dari sisi internal pasti sekolah terus berbenah dan memberikan yang terbaik agar tetap menjadi pilihan orangtua dan siswa. Mulai dari perbaikan dari sisi pembelajaran, kualitas pengajaran, pelayanan, peningkatan sarana prasarana, termasuk peningkatan akreditasi dari tahun ketahun, agar memiliki daya tarik tersendiri. Gaya kepemimpinan dalam teori leadership juga dapat di terapkan untuk kepala sekolah, yang tentunya akan berpengaruh dalam proses yang berjalan di sekolah tersebut.

Konsep gaya kepemimpinan adalah salah satu yang sering diperdebatkan dalam literatur, dengan penulis yang berbeda menggunakan istilah (gaya, bentuk, pendekatan, strategi, model) untuk mengkategorikan praktik atau teori kepemimpinan. Gaya kepemimpinan secara sederhana, merupakan pola perilaku yang ditampilkan oleh pemimpin, selain itu gaya kepemimpinan merupakan label yang terutama menangkap pendekatan gaya atau metodologi yang berbeda untuk mencapai tujuan penting yang penting untuk keefektifan organisasi mana pun. Tujuan yang dimaksud, termasuk pengaturan arah dan bergerak menuju pencapaian arah yang ditetapkan, dalam organisasi tertentu. Segudang gaya kepemimpinan (termasuk; demokratis, otoriter, instruksional, transformasional, transaksional) telah diidentifikasi dan dikaitkan dengan praktik kepemimpinan yang berbeda dalam mengejar tugas dan tujuan organisasi. Literatur menunjukkan bahwa gaya kepemimpinan yang berbeda tampaknya berhasil untuk pemimpin yang berbeda dalam 
situasi yang berbeda, yang mengarah ke pernyataan bahwa tidak ada gaya kepemimpinan tunggal yang terbaik, karena faktanya pemimpin yang paling sukses cenderung mengadopsi sebagian besar atau semua gaya yang berbeda. Sebagian besar gaya kepemimpinan didefinisikan melalui kata sifat belaka yang harus menarik skeptisisme, daripada penerimaan. Kepemimpinan demokratis lebih efektif ketika 'muncul' daripada dipaksakan secara eksternal. Secara internasional, karya yang lebih baru tentang gaya kepemimpinan membuat perbandingan antara gaya kepemimpinan transaksional dan transformasional, serta dengan pendekatan kepemimpinan terdistribusi. Fokus pada gaya kepemimpinan transformasional menyarankan bahwa pemimpin yang menampilkan perilaku transformasional memotivasi, menginspirasi, membimbing dan memberdayakan pengikut dengan visi bersama dan pengambilan keputusan partisipatif. Sebaliknya, pemimpin transaksional adalah mereka yang menampilkan perilaku yang lebih tradisional yang menetapkan tanggung jawab yang jelas untuk bawahan dan memberi penghargaan kepada mereka untuk kinerja dan kesuksesan yang memuaskan, memperbaiki kesalahan dan kegagalan. Dengan demikian, gaya kepemimpinan sebagai istilah khusus untuk merujuk pada pendekatan, strategi, atau bentuk kepemimpinan yang berbeda yang dilakukan oleh para pemimpin di tingkat distrik, untuk menyatakan bahwa beberapa gaya kepemimpinan atau beberapa kombinasi gaya kepemimpinan lebih cenderung mengarah pada peningkatan sekolah daripada yang lain (Moorosi \& Bantwini, 2016).

\section{Pengaruh Gaya Kepemimpinan di Sekolah}

Gaya kepemimpinan desentralisasi yang menghasilkan kepemimpinan pedagogis yang efisien adalah salah satu kerja tim dan kerjasama. Semakin banyak sekolah berhasil berbagi dengan staf profesional keputusannya (koordinator, staf administrasi) semakin dapat diharapkan keterlibatan yang lebih besar di pihak mereka, identifikasi dan komitmen pribadi untuk memenuhi kebijakan kelembagaannya. Gaya kepemimpinan, yang sebagian besar ditujukan untuk membina hubungan antarpribadi akan mengekspresikan keintiman yang lebih tinggi dan dorongan kuat ke arah pertimbangan yang lebih besar. Sangat sedikit sekolah yang mengubah manajemen pendidikannya secara signifikan. Kepala sekolah memiliki peran penting dalam menciptakan lingkungan yang positif dan memelihara guru. Harapan guru dari kepala sekolah adalah menerima dukungan, menetapkan bidang tanggung jawab yang jelas, menetapkan tujuan, memberikan umpan balik, dorongan, informasi, menciptakan komunikasi yang baik dan interaksi profesional yang efektif antara anggota staf. Selain itu, kepala sekolah bertanggung 
jawab untuk menciptakan suasana sekolah yang terbuka, terorganisir dan berorientasi pada tujuan. Sangat penting untuk menumbuhkan sisi guru dalam hubungan dengan administrasi terutama di tahun-tahun awal pengajaran. Kepala sekolah bertanggung jawab untuk menciptakan lingkungan yang mendukung mulai dari sisi administrasi dan guru berpengalaman hingga guru baru (Wasserman, Ben-eli, Yehoshua \& Gal, 2016).

\section{METODE PENELITIAN}

Penelitian ini menggunakan metode deskriptif kualitatif dengan studi kasus. Sumber data dalam penelitian kualitatif adalah kata-kata dan tindakan. Selebihnya adalah data tambahan seperti rekaman dan kuesioner form wawancara dari para staff yang dipimpin. Pengumpulan data dilakukan dengan wawancara dengan kepala sekolah (informan kunci) dan data pendukung dari para followers (staff). Data yang diperoleh ada rekaman wawancara yang akan penulis lakukan verbatim dan analisis terhadap data angket yang telah dilakukan kepada para pegawai. Penelitian ini dilakukan di sekolah dasar islam Al-Azhar Sriwijaya yang bertempat di Jakabaring, kota Palembang, Sumatera Selatan. Penelitian dilakukan pada obyek yang berkembang apa adanya tidak dimanipulasi oleh peneliti dan kehadiran peneliti tidak begitu mempengaruhi dinamika pada obyek tersebut (Sugiyoni, 2010)

Dalam penelitian ini penulis menggunakan teknik tringgulasi dalam mendapatkan validitas data.
Konsep tringgulasi berarti membandingkan data yang diperoleh dari berbagai sumber. Selain data utama berupa wawanca dengan kepala sekolah, peneliti memiliki data survey deskriptif kepada pegawai dan data observasi yang dilakukan peneliti di sekolah tersebut. Peneliti akan membandingkan data hasil wawancara dan hasil survey pegawai, membandingkan apa yang dikatakan di depan umum dan wawancara pribadi, dan membandingkan keadaan persepsi (khususnya) kepala sekolah dengan persepsi orang lain dengan berbagai pendapat atau pandangan.

Pertanyaan wawancara kepada informan utama dan pendamping berfokus kepada 4 hal yaitu :

1. Pengambilan keputusan sekolah

2. Komunikasi \& administrasi

3. Budaya \& organisasi, dan

4. Teknologi \& sistem informasi

Proses tringulasi diterapkan untuk mengetahui tipe tipe kepemimpinan kepala sekolah, menganalisa akibat dari gaya kepemimpinan yang dijalankan dan akhirnya penulis akan memberikan saran yang diharapkan dapat memberika benefit untuk sekolah kedepannya.

\section{HASIL PENELITIAN}

\section{Pengambilan}

\section{Sekolah}

Sebagian besar keputusan di sekolah dilaksanakan dengan musyawarah. Terkecuali untuk peraturan prinsip seperti peraturan sekolah dan peraturan guru. Menurut semua staff / guru, hampir semua pendapat diterima, tetapi memang keputusan akhir akan diputuskan oleh kepala sekolah. Karena menurut guru dan 
kepala sekolah sendiri, kepala sekolah adalah penentu cita-cita sekolah sekarang dan kedepannya. Termasuk jika ada perubahan (contoh pada keadaan pandemic) yang mengharuskan merubah kebijakan metode pembelajaran. Dalam hal ini dapat disimpulkan gaya kepemimpinan yang dipakai adalah demokratis dengan kombinasi transformational yagn berfokus kepada peningkatan sekolah sesuai dengan penelitian Moorosi \& Bantwini, 2016.

\section{Komunikasi \& Administrasi}

Hampir semua guru mengatakan, gaya komunikasi yang digunakan ramah tetapi tegas. Ramah pada semua tetapi tegas apabila terjadi kesalahan atau ketidaksesuaian dengan pandangan kepala sekolah. Dari hasil wawancara, kepala sekolah selalu melaksanakan rapat mingguan dan rapat bulanan. Dengan tujuan utama untuk menjaga ritmen dan jalannya sekolah sesuai dengan perencanaan. Dan tentunya antisipasi apabila ada yang berubah di tengah perjalanan. Kepala sekolah bertugas untuk menciptakan lingkungan yagn sehat secara komunikasi dan terstruktur. Berhubungan dengan komunikasi tentunya dalam hal administratif. Kepala sekolah berpendapat tidak semua guru harus sama perlakuanya (dalam hak dan kewajiban). Tentunya sistem ini didasari guru yang lebih lama bekerja dan baru. Tetapi bukan berarti guru baru tidak bisa melangkahi guru lama secara karir, tetapi juga dalam administrasi sekolah ditekankan semua guru diberikan tugas tambahan (seperti mengurus aset, kurikulum, jadwal dll) dan dapat digunakan untuk evaluasi guru tersebut kedepannya. Sesuai dengan penelitian sebelumnya, sangat penting untuk menumbuhkan sisi guru dalam hubungan dengan administrasi terutama di tahuntahun awal pengajaran. Kepala sekolah bertanggung jawab untuk menciptakan lingkungan yang mendukung mulai dari sisi administrasi dan guru berpengalaman hingga guru baru (Wasserman, Ben-eli, Yehoshua \& Gal, 2016).

\section{Budaya \& Organisasi}

Kepala sekolah harus menularkan budaya yang baik dan membangun di sekolah. Dengan mengembangkan budaya perubahan (kearah yang lebih baik) menjadi salah satu faktor terciptanya manajemen sekolah yang lebih efektif sesuai dengan penelitian Vally \& Daud tahun 2015. Guru yang berprestasi akan diberi reward, dan yang melakukan kesalahan akan diberikan teguran dan juga bimbingan / arahan agar kesalahan tidak terulang kembali. Dari segi kedisplinan, kepala sekolah juga cukup tegas dalam menindak kesalahan-kesalahan dasar seperti terlambat dan tidak terpengaruh oleh kedekatan pribadi dengan beberapa guru / staff. Menurut sebagian besar guru dan staff, kepala sekolah juga membuka pengembangan pendidikan yang lebih tinggi dan beberap pelatihan untuk menopang pengembangan diri dari semua staff agar tercipta budaya perubahan yang lebih baik 
dan maju. Ditambah kepala sekolah sering memberikan informasi terkait informasi pelatihan-pelatihan dari luar (diknas atau swasta) untuk seluruh staff agar selalu meningkatkan kemampuan diri. Berhubungan dengan point organisasi, pola komunikasi dan hubungan dengan orang tua murid juga dilakukan dengan baik oleh kepala sekolah. Sehingga memudahkan guru-guru untuk mempraktekan gaya komunikasi yang sejenis dengan orang tua. Hal ini penting mengingat orang tua murid dapat membantu pengembangan sekoah dan menjadikan kerja sekolah menjadi lebih efektif. Sesuai dengan penelitian sebelumnya yang menyatakan dukungan orang tua yang memadai terhadap guru akan memfasilitasi hasil belajar siswa yang positif di sekolah (Abdulrasheed, Hussin \& Kasa, 2016).

\section{Teknologi \& Sistem Informasi}

Penerapan pengembangan sistem informasi dan teknologi sudah sangat baik diterapkan oleh kepala sekolah. Penggunaan email, whatsapp dan sosial media telah dilaksanakan dalam membantu hubungan komunikasi dan kordinasi dengan guru, staff dan orang tua murid. Sebagian besar guru dam staff menyatakan, kepala sekolah beberapa kali mengingatkan untuk peka terhadap teknologi. Kepala Sekolah juga beranggapan jika guru dan staff tidak mengejar ketinggalan di bidang teknologi dan sistem informasi, akan tertinggal kedepannya terutama dengan guru-guru muda / baru yang lebih fresh dan lebih peka terhadap kemajuan teknologi dan sistem informasi.

Sistem pembelajaranpun sudah siap untuk hybrid (offline dan online) dan pemanfaatan teknologi seperti zoom atau google meet telah dimanfaatkan dengan baik oleh kepala sekolah, guru / staff, orang tua murid dan murid. Sesuai dengan penelitian sebelumnya Sekolah yang memiliki kepemimpinan kepala sekolah yang kuat diharapkan mampu mengembangkan manajemen sekolah yang efektif, karena didukung oleh berbagai aspek, seperti penerapan teknologi, budaya sekolah, sistem informasi, dan organisasi yang berkembang (Vally \& Daud, 2015).

\section{PENUTUP}

Gaya kepemimpinan kepala sekolah menentukan dalam proses penerapan manajemen sekolah yang lebih efektif. Pada penelitian ini juga menunjukan, perpaduan / kombinasi gaya kepemimpinan lebih baik diterapkan dibanding dengan satu gaya kepemimpinan saja. Kepala sekolah SDI Al-Azhar Sriwijaya menerapkan beberapa gaya kepemimpinan yang digunakan untuk berbagai hal. Demokratis dalam rapat, konserfatif dalam peraturan dan transformasional dalam membuat planning bersama agar bisa selalu memotivasi, menginspirasi, membimbing dan memberdayakan pengikut dan visi bersama dan pengembalian keputusan partisipatif. Gaya kepemimpinan atau beberapa kombinasi gaya kepemimpinan lebih cenderung mengarah pada peningkatan sekolah daripada yang 
lain (Moorosi \& Bantwini, 2016). Dalam penelitian ini juga menyatakan menunjukkan bahwa gaya kepemimpinan yang berbeda tampaknya berhasil untuk pemimpin yang berbeda dalam situasi yang berbeda, yang mengarah ke pernyataan bahwa tidak ada gaya kepemimpinan tunggal yang terbaik, karena faktanya pemimpin yang paling sukses cenderung mengadopsi sebagian besar atau semua gaya yang berbeda. Tentunya kombinasi gaya kepemimpinan ini memiliki tujuan akhir memaksimalkan seluruh potensi stakeholders yang ada di sekolah yaitu guru /staff, orang tua murid dan murid agar dapat membantu dalam penerapan manajemen sekolah yang lebih efektif.

\section{DAFTAR PUSTAKA}

Abdulrasheed, O., \& Bello, A.S. (2015). Challenges to Secondary School Principals' Leadership in Northern Region of Nigeria. British Journal of Education, 3 (3), pp. 1-5.

Abdulrasheed, O., Hussin, F., \& Kasa, M.D. (2016). Challenges of Principal Leadership Styles and School Management: A Solution Oriented Approach. Asia Pacific Journal of Education, Arts and Sciences, 3 (4), pp.61-68.

Badau, K.M., \& Abdulrasheed, O. (2015). Management of Emergency Peace Education Programmes for Boko Haram Internally Displaced Persons in Yola Refugee Camp of Adamawa State Nigeria. Journal of Social Science Studies, 2 (1), pp. 36-45.
Imhangbe, O., Okecha, R., \& Obozuwa, J. (2018). Principals' leadership styles and teachers' job performance: Evidence from Edo State, Nigeria. Educational Management Administration \& Leadership, 47 (6), pp. 1-16.

Moorosi, P., \& Bantwini, B.D. (2016). School district leadership styles and school improvement: evidence from selected school principals in the Eastern Cape Province. South African Journal of Education, 36 (4), pp. 1-9.

Saleem, A., Aslam, S., Yin, H.-b., \& Rao, C. (2020). Principal Leadership Styles and Teacher Job Performance: Viewpoint of Middle Management. Sustainability, 12, pp. 1-15.

Sunaengsih, C., Anggarani, M., Amalia, M., Nurfatmala, S., \& Naelin, S.D. (2019). Principal Leadership in the Implementation of Effective School Management. Mimbar Sekolah Dasar, 6 (1), pp. 79-91.

Vally, G. V. S., \& Daud, K. (2015). The Implementation of School Based Management Policy: An Exploration. Procedia - Social and Behavioral Sciences, 172, pp. 693-700.

Wasserman, E., Ben-eli, S., Yehoshua, O., \& Gal, R. (2016). Relationship between the Principal's Leadership Style and Teacher Motivation. International Journal of Learning, Teaching and Educational Research, 15 (1), pp. 180-192. 